\title{
Pengembangan Perangkat Pembelajaran Matematika Berbasis Model Problem Based Learning untuk Memfasilitasi Kemampuan Pemecahan Masalah Siswa Kelas VIII SMP/MTs
}

\author{
Reny Reski ${ }^{1}$, Nahor Murani Hutapea ${ }^{2}$, Sehatta Saragih ${ }^{3}$ \\ 1,2,3 Pendidikan Matematika, Universitas Riau \\ Kampus Bina Widya KM.12,5, Simpang Baru, Kecamatan Tampan, Kota Pekanbaru, Riau, Indonesia \\ renyreski@gmail.com
}

\begin{abstract}
This article is based on the low ability of students to solve mathematical problems, and the weakness of teachers in preparing lesson plans and LAS. This article aims to analyze the results of the validation of mathematical learning tools based on a problem-based learning model on the material of flat-sided shapes. The model used in this development is the ADDIE development models but it is limited to four stages, namely the analysis, design, development and implementation stages. The research instrument used in this article was a validation sheet (validity aspect in the form of a questionnaire), two lecturers and a math teacher assessment sheets and an assessment sheet by twelve students (practicality aspect in the form of a questionnaire). The data analysis used in this article is a descriptive analysis using a Likert scale score. From the analysis, it is concluded that this research produces mathematical learning tools based on a problem based learning model on the valid and practical material of flat-sided shapes.
\end{abstract}

Keywords: Mathematics Learning Tools, Problem Based Learning, Problem Solving

\begin{abstract}
Abstrak
Artikel ini didasari oleh rendahnya kemampuan pemecahan masalah matematis siswa, dan lemahnya guru dalam menyusun RPP dan Lembar Aktivitas Siswa (LAS). Artikel ini memiliki tujuan untuk menganalisis hasil validasi perangkat pembelajaran matematika berbasis model problem based learning pada materi bangun ruang sisi datar. Model yang digunakan dalam pengembangan ini adalah model pengembangan ADDIE namun dibatasi pada empat tahap, yaitu tahap analisis, perancangan, pengembangan, dan implementasi. Instrumen penelitian yang digunakan dalam artikel ini adalah lembar validasi (aspek kevalidan berupa angket), lembar penilaian dua orang dosen dan satu orang guru matematika serta lembar penilaian oleh dua belas siswa (aspek kepraktisan berupa angket). Analisis data yang digunakan dalam artikel ini adalah analisis deskriptif melalui skor skala likert. Dari hasil analisis diperoleh kesimpulan bahwa penelitian ini menghasilkan perangkat pembelajaran matematika berbasis model problem based learning pada materi bangun ruang sisi datar yang valid dan sangat praktis untuk memfasilitasi kemampuan pemecahan masalah matematis siswa.
\end{abstract}

Kata kunci: Perangkat pembelajaran matematika, Problem Based Learning, kemampuan pemecahan masalah matematis

Copyright (c) 2021 Reny Reski, Nahor Murani Hutapea, Sehatta Saragih

$\triangle$ Corresponding author: Reka Damaiyanti

Email Address: renyreski@gmail.com_(Kampus Bina Widya KM.12,5, Kota Pekanbaru, Riau,)

Received 05 November 2020, Accepted 18 Januari 2021, Published 24 Maret 2021

\section{PENDAHULUAN}

Pembelajaran matematika di jenjang pendidikan dasar dan menengah bertujuan agar siswa: (1) Memahami konsep matematika, menjelaskan keterkaitan antarkonsep dan mengaplikasikan konsep atau algoritma, secara luwes, akurat, efisien, dan tepat, dalam pemecahan masalah; (2) Menggunakan penalaran pada pola dan sifat, melakukan manipulasi matematika dalam membuat generalisasi, menyusun bukti, atau menjelaskan gagasan dan pernyataan matematika; (3) Memecahkan masalah yang 
meliputi kemampuan memahami masalah, merancang model matematika, menyelesaikan model dan menafsirkan solusi yang diperoleh; (4) Mengomunikasikan gagasan dengan simbol, tabel, diagram, atau media lain untuk memperjelas keadaan atau masalah; (5) Memiliki sikap menghargai kegunaan matematika dalam kehidupan, yaitu memiliki rasa ingin tahu, perhatian, dan minat dalam mempelajari matematika, serta sikap ulet dan percaya diri dalam pemecahan masalah (Kamarullah, 2017).

Pembelajaran matematika sangat penting karena merupakan sarana untuk memecahkan masalah kehidupan sehari-hari (Kusmanto \& Marliyana, 2014). Permendikbud nomor 22 tahun 2016 menyatakan bahwa pembelajaran yang disarankan dalam kurikulum 2013 adalah pembelajaran yang menghasilkan karya berbasis pemecahan masalah. Sulistyowati et al, menyatakan bahwa kemampuan pemecahan masalah merupakan hal yang sangat penting bagi siswa dalam belajar, karena siswa cepat lupa jika hanya dijelaskan secara lisan, mereka akan ingat jika diberikan contoh, dan memahami jika diberikan kesempatan mencoba memecahkan masalah (Supriadi et al., 2019). Dalam pendidikan, kemampuan siswa diasah melalui masalah, sehingga siswa mampu meningkatkan berbagai kompetensi yang dimilikinya (Sumartini, 2016). Oleh sebab itu, perlu penguatan kemampuan yang mengintegrasikan informasi, menarik simpulan, serta menggeneralisir pengetahuan yang dimiliki ke hal-hal yang lain (Pai'pinan \& Kho, 2018). Kemampuan penalaran diperlukan dalam pembelajaran matematika yang menekankan pada aspek kemampuan pemecahan masalah matematis (KPMM). KPMM tidak hanya dibutuhkan siswa ketika belajar matematika, tetapi dibutuhkan agar siswa dapat menganalisis setiap masalah, memecahkan masalah dengan tepat, dapat menilai sesuatu secara kritis dan obyektif serta dapat menarik kesimpulan secara logis (Susilowati, 2016).

KPMM sangat terkait dengan kemampuan siswa dalam membaca dan memahami bahasa soal cerita, menyajikan dalam model matematika, merencanakan perhitungan dari model matematika, serta menyelesaikan perhitungan dari soal-soal yang tidak rutin (Anisa, 2014). KPMM sangat penting dimiliki oleh setiap siswa karena: (1) pemecahan masalah merupakan tujuan umum pembelajaran matematika; (2) pemecahan masalah yang meliputi metode, prosedur dan strategi merupakan proses inti dan utama dalam kurikulum matematika; dan (3) pemecahan masalah merupakan kemampuan dasar dalam belajar matematika (Nurfatanah et al., 2019), (Sumartini, 2016). Namun, pentingnya kemampuan pemecahan masalah matematis tidak sesuai dengan kondisi yang terjadi di sekolah.

Hasil TIMSS (Trend in International Mathematics and Science Study) tahun 2015, menunjukkan siswa Indonesia berada di peringkat 44 dari 49 negara dengan rata-rata skor 397 jauh di bawah skor rata-rata internasional yaitu 500. Tidak jauh berbeda dari TIMSS, hasil dari Program for International Student Assesment (PISA) tahun 2018 bidang matematika menunjukkan bahwa siswa Indonesia mendapat peringkat 72 dari 80 negara di dunia dengan skor 379 mengalami penurunan jika dibandingkan dengan hasil PISA tahun 2015 yaitu pada skor 386 (Hamidy \& Jailani, 2019). TIMSS merupakan penilaian dan perancangan penelitian secara internasional untuk mengevaluasi prestasi pendidikan khususnya dalam bidang matematika dan sains. Pengkajian matematika dalam TIMSS diukur dalam dua aspek, yaitu aspek konten yang digunakan untuk menentukan materi pelajaran yang 
Pengembangan Perangkat Pembelajaran Matematika Berbasis Model Problem Based Learning untuk Memfasilitasi Kemampuan Pemecahan Masalah Siswa Kelas VIII SMP/MTs, Reny Reski, Nahor Murani Hutapea, Sehatta Saragih 703

berupa bilangan, bentuk dan ukuran geometri, serta data, dan aspek kognitif untuk menentukan proses berpikir yang digunakan siswa yang terkait dengan knowing, applying, dan reasoning (Bidasari, 2017). Hasil Penelitian Ningsih et al. (2020) menunjukkan analisis KPMM dari jumlah 38 siswa dengan hasil bahwa: (1) 52,63\% siswa tidak dapat mengidentifikasi apa yang diketahui dan ditanyakan dengan benar; (2) $65,79 \%$ siswa belum dapat menggunakan konsep dan formula berdasarkan masalah yang diberikan dengan benar; (3) 60,53\% siswa belum mampu menghitung dan menyelesaikan masalah dengan benar; dan (4) 60,53\% siswa belum dapat menuliskan kesimpulan berdasarkan masalah awal dengan benar. Berdasarkan hasil PISA dan TIMSS tersebut, menunjukkan bahwa secara umum kemampuan matematis siswa Indonesia masih tergolong rendah di semua aspek (membaca, matematika, dan sains).

Melihat masih rendahnya kemampuan pemecahan masalah matematis siswa, maka perlu adanya upaya-upaya guru dalam meningkatkannya, dengan memperhatikan karakteristik siswa dan tujuan pembelajaran. Dalam kurikulum 2013 yang menggunakan pendekatan saintifik, dengan tahapan belajar, yaitu observing, questioning, experimenting, associating, dan communicating (Susilana \& Ihsan, 2014). Dalam implementasi penelitian ini, diperlukan model pembelajaran yang sejalan yang dapat mengoptimalkan kemampuan pemecahan masalah matematis siswa. Salah satu model pembelajaran yang direkomendasikan dalam kurikulum 2013 yang dapat digunakan untuk meningkatkan kemampuan siswa yaitu Problem Based Learning (PBL) (Arends, 2012). PBL merupakan pendekatan pembelajaran yang berpusat pada siswa yang mengorganisasikan kurikulum dan pembelajaran dalam situasi yang tidak terstruktur dan memberikan masalah dunia nyata (Arends, 2012). Karakteristik masalah yang diajukan dalam PBL berupa masalah autentik yang dijadikan tonggak untuk melakukan investigasi dan penemuan. Selain itu dalam praktiknya, penerapan PBL menuntut agar siswa berkolaborasi dan mengatur pembagian tugas antar siswa (Arends, 2012). Pembelajaran matematika selanjutnya diharapkan dapat menerapkan suatu model pembelajaran yang memberikan kesempatan lebih luas kepada siswa untuk melakukan kegiatan penyelidikan dan menemukan langkah-langkah pemecahan masalah secara mandiri.

Untuk mengoptimalkan pembelajaran matematika maka diperlukan untuk mengembangkan perangkat pembelajaran yang mengacu pada penerapan model PBL. Perangkat pembelajaran yang dimaksud, adalah silabus, RPP dan LAS bercirikan model PBL. Dalam kurikulum 2013, dinyatakan bahwa perangkat pembelajaran merupakan kebutuhan mendasar yang harus dimiliki seorang guru sebelum memulai proses pembelajaran. Seorang guru harus mempersiapkan perencanaan pembelajaran yang dirancang dalam bentuk silabus dan rencana pelaksanaan pembelajaran (RPP) yang mengacu pada standar isi (Permendikbud No 65 tahun 2013). Perangkat pembelajaran sangat penting, karena merupakan acuan guru untuk melaksanakan kegiatan pembelajaran supaya lebih terarah dan sistematis.

Hasil beberapa penelitian tentang perangkat pembelajaran yang digunakan guru di sekolah belum sesuai dengan kurikulum 2013 (Kartika et al., 2020); (Putri et al., 2020); (Rianti et al., 2020). Perangkat pembelajaran yang digunakan guru seperti RPP yang disusun belum mengacu pada komponen RPP yang dikemukakan Permendikbud No 22 tahun 2016 contoh IPK yang belum menggunakan kata 
kerja opersional, rincian kegiatan pembelajaran belum sesuai dengan model pembelajaran yang digunakan, pendekatan saintifik belum terlihat dan langkah-langkah model pembelajaran yang digunakan belum terlihat pada kegiatan pembelajaran (Kartika, et al., 2020). Sejalan dengan pendapat Rianti et al. (2020) \& Putri et al. (2020) bahwa masih banyak guru yang belum optimal dalam mengembangkan perangkat pembelajaran seperti guru kesulitan mengembangkan LAS yang dapat mendorong siswa untuk menemukan sendiri konsep dari materi yang dipelajari sebagai wahana mengembangkan kemampuan matematis siswa.

Berdasarkan hasil analisis yang peneliti lakukan terhadap perangkat pembelajaran yang digunakan guru pada beberapa MTs di Kampar. Peneliti mendapatkan bahwa perangkat yang dibuat guru belum dapat mengoptimalkan pembelajaran. Kelemahan pertama yaitu penyusunan RPP, dalam penyusunan RPP guru pada indicator pencapaian kompetensi berdasarkan KD belum menggunakan kata kerja operasional (KKO) yang tepat, selain itu dalam pembuatan RPP guru masih menggunakan pembelajaran yang konvensional. Kelemahan kedua yaitu sumber belajar yang digunakan guru merupakan buku paket dan LAS yang disediakan sekolah yang berasal dari penerbit. LAS yang digunakan hanya berisi ringkasan materi yang terstruktur dan latihan soal-soal rutin yang kurang memfasilitasi kemampuan pemecahan matematis siswa.

Berdasarkan rasional yang diuraikan di atas maka masalah yang akan dikaji adalah Pengembangan Perangkat Pembelajaran Matematika Melalui Model Problem Based Learning (PBL) yang valid dan praktis untuk memfasilitasi siswa dalam mengembangkan Kemampuan Pemecahan Masalah Matematis Siswa Pada Materi Bangun Ruang Sisi Datar Kelas VIII SMP/MTs.

\section{METODE}

Penelitian ini merupakan jenis penelitian pengembangan (research and development). Model yang digunakan dalam pengembangan ini adalah model pengembangan ADDIE yang dirancang oleh Dick dan Carry (Mulyatiningsih, 2012). Produk dari penelitian ini adalah perangkat pembelajaran berbasis problem based learning untuk siswa kelas VIII MTs. Perangkat yang dikembangkan yaitu silabus, Rencana Pelaksanaan Pembelajaran (RPP) dan Lembar Aktifitas Siswa (LAS). Uji coba kelompok kecil pada penelitian ini terdiri dari 12 orang dari kelas VIII MTsN 8 kampar yang dipilih secara acak dengan kemampuan yang heterogen, yaitu siswa dengan kemampuan rendah, sedang, dan tinggi. Uji coba skala kecil bertujuan untuk melihat keterbacaan LAS dengan model PBL pada materi bangun ruang sisi datar yang telah dikembangkan. Siswa diminta untuk mengerjakan LAS yang telah dikembangkan dan mengisi angket respon siswa. Penelitian ini hanya dibatasi sampai empat tahapan dikarenakan terbatasnya waktu dalam mengumpulkan peserta didik di masa pandemi Covid-19, yaitu: tahap analisis, (2) tahap perancangan, (3) tahap pengembangan, dan (4) tahap implementasi. Model desain ADDIE dapat dilihat pada gambar berikut: 


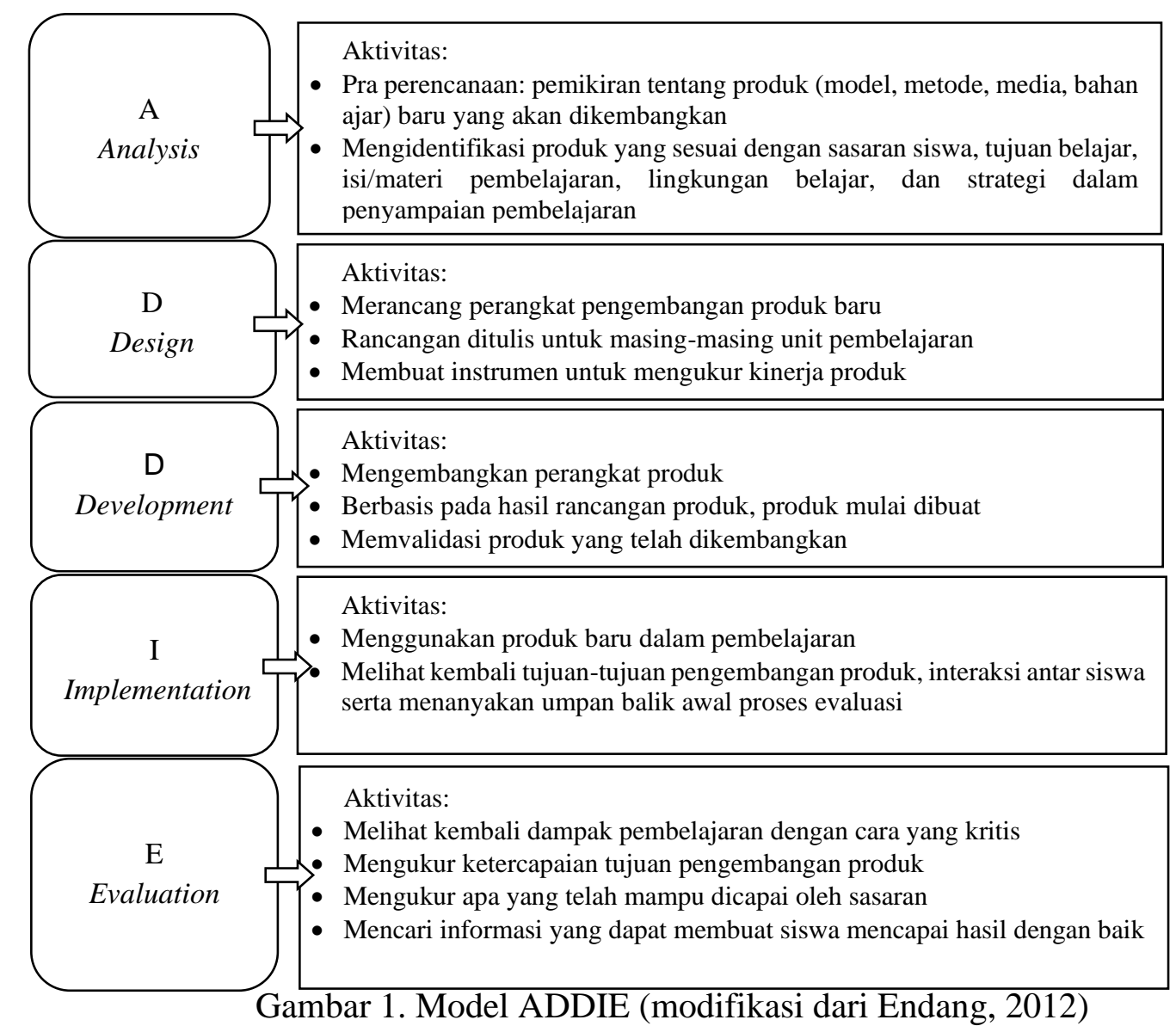

Instrumen penelitian yang digunakan adalah lembar validasi silabus, RPP, LAS, dan angket respon siswa dengan menggunakan format skala perhitungan rating scale. Skala perhitungan rating scale terdiri dari empat alternatif jawaban, yaitu 1, 2, 3, dan 4, yang menyatakan sangat tidak sesuai, tidak sesuai, sesuai, dan sangat sesuai. Sedangkan angket respon siswa menggunakan skala guttman yang terdiri dari 2 alternatif jawaban, ya dan tidak. Analisis data yang digunakan adalah analisis deskriptif melalui skor skala likert. Akbar (2013) menyatakan bahwa dalam analisis tingkat validitas secara deskriptif dapat menggunakan rumus berikut:

$$
V a_{x}=\frac{T S e}{T S h} \times 100 \%
$$

Keterangan:

TSe: Total skor empiris (hasil validasi dari validator)

$T S h$ : Total skor maksimal yang diharapkan

$V_{a}$ : Validator ahli, berdasarkan setiap Silabus, RPP, dan LAS dengan $x=1,2,3$

Untuk mengetahui hasil akhir validasi Silabus, RPP, dan LAS dari para ahli maka dihitung dengan menggunakan rumus rata-rata (mean). Adapun rumus validasi akhir sebagai berikut:

$$
V=\frac{V a_{1}+V a_{2}+V a_{3}}{3}
$$

Keterangan: V= Validitas akhir

$$
V a_{1}=\text { Validitas ahli } 1
$$




$$
\begin{aligned}
& V a_{2}=\text { Validitas ahli } 2 \\
& V a_{3}=\text { Validitas ahli } 3
\end{aligned}
$$

Hasil validasi masing-masing validator dan hasil analisis rata-rata dari validator, tingkat persentasenya dapat dicocokkan dengan kategori validitas seperti pada Tabel 1 berikut.

Tabel 1. Kategori Validitas Silabus, RPP, dan LAS

\begin{tabular}{|c|l|}
\hline Interval & \multicolumn{1}{|c|}{ Kategori } \\
\hline $85,01 \%-100,00 \%$ & Sangat valid, atau dapat digunakan tanpa revisi \\
\hline $70,01 \%-85,00 \%$ & Cukup valid, atau dapat digunakan namun perlu revisi kecil \\
\hline $50,01 \%-70,00 \%$ & Kurang valid, disarankan tidak dipergunakan karena perlu revisi besar \\
\hline $01,00 \%-50,00 \%$ & Tidak valid, atau tidak boleh dipergunakan. \\
\hline
\end{tabular}

Sumber: Akbar (2013)

Berdasarkan Tabel 1, perangkat pembelajaran dikatakan valid jika rata-rata validasi dikategorikan cukup valid atau sangat valid. Analisis angket respon peserta didik dilakukan untuk melihat kepraktisan LAS yang dikembangkan menggunakan rumus modifikasi dari Akbar (2013). Untuk mengetahui hasil akhir respon peserta didik maka dihitung dengan menggunakan rumus rata-rata (mean).

$$
R=\frac{\sum P}{\text { jumlah peserta didik }}
$$

Keterangan: $R=$ Hasil akhir respon peserta didik

$\sum P=$ Jumlah persentase kepraktisan

Nilai yang diperoleh kemudian diinterprestasikan dengan kategori kepraktisan pada Tabel 2 berikut.

Tabel 2. Kategori Kepraktisan

\begin{tabular}{|c|c|}
\hline Interval & Kategori \\
\hline $85,01 \%-100,00 \%$ & Sangat Praktis \\
\hline $70,01 \%-85,00 \%$ & Praktis \\
\hline $50,01 \%-70,00 \%$ & Kurang Praktis \\
\hline $01,00 \%-50,00 \%$ & Tidak Praktis \\
\hline
\end{tabular}

Sumber: Akbar (2013)

Berdasarkan Tabel 2, perangkat pembelajaran dikatakan praktis jika rata-rata validasi dikategorikan praktis atau sangat praktis.

\section{HASIL DAN DISKUSI}

Hasil dari penelitian pada materi bangun ruang sisi datar ini berupa: (1) deskripsi hasil pengembangan dengan tahapan model ADDI (Analysis, Design, Development, dan Implementation); dan (2) deskripsi hasil pengembangan perangkat pembelajaran yang memenuhi kriteria valid dan praktis.

\section{Tahap Analisis (Analysis)}

Tahap pertama pada penelitian pengembangan ini adalah tahap analisis. Kegiatan utama adalah menganalisis perlunya pengembangan produk yang baru dan menganalisis kelayakan dan syarat-syarat pengembangan produk baru. Tahap analisis terdiri dari dua tahap, yaitu analisis kinerja (performance 
analysis) dan analisis kebutuhan (need analysis). Pada tahap analisis kinerja dilakukan pengumpulan informasi mengenai permasalahan yang terdapat dalam pembelajaran matematika di sekolah. Berdasarkan hasil observasi yang dilakukan diperoleh kesimpulan bahwa proses pembelajaran matematika masih berpusat pada guru, LAS yang digunakan masih menggunakan soal-soal rutin, sehingga kurang mendukung pengembangan kemampuan pemecahan masalah matematis siswa.

Berdasarkan analisis kinerja yang disajikan agar bisa mengoptimalkan kualitas pembelajaran dibutuhkan perangkat perangkat pembelajaran yang sesuai dengan kebutuhan siswa. Kemudian peneliti melakukan analisis kebutuhan dengan cara observasi siswa, sehingga diperoleh bahwa siswa masih menjadi objek penerima informasi presentase lisan guru, pembelajaran cenderung berpusat kepada guru, dan kurang melibatkan siswa dalam proses pembelajaran. Selain itu KPMM siswa hanya siswa yang pandai yang bisa menyelesaikan soal tes KPMM tersebut, siswa juga tidak menuliskan apa yang diketahui dan ditanya.

Berdasarkan analisis kebutuhan tersebut, agar terjadi proses pembelajaran yang menyenangkan dan efektif bagi siswa salah satu alternatif penyelesaian adalah dengan menyediakan perangkat pembelajaran yang dapat menunjang tercapainya tujuan pembelajaran yang diinginkan. Sebagai salah satu alternatif, peneliti mengembangkan perangkat pembelajaran matematika SMP Kelas VIII pada materi pokok bangun ruang sisi datar dengan model PBL.

\section{Tahap Perancangan (Design)}

Pada tahap ini, peneliti mendesain perangkat pembelajaran dan instrumen yang digunakan dalam penelitian. Berdasarkan analisis yang telah dilakukan, selanjutnya dilakukan pengumpulan referensi yang relevan sebagai bahan untuk mendesain perangkat pembelajaran pada materi bangun ruang sisi datar dan instrumen penelitian.

Rancangan silabus. Komponen silabus memuat identitas pelajaran, identitas sekolah, kompetensi inti, kompetensi dasar, materi pokok, kegiatan pembelajaran, penilaian, alokasi waktu, dan sumber belajar. Kegiatan pembelajaran disusun dengan langkah-langkah model Problem Based Learning, yaitu (1) orientasi siswa pada masalah diterapkan melalui kegiatan mengamati; (2) tahap mengorganisasi siswa untuk belajar diterapakan melalui kegiatan membuat diketahui dan ditanya; (3) tahap membimbing penyelidikan kelompok; (4) tahap mengembangkan dan menyajikan hasil karya; dan (5) tahap menganalisis dan mengevaluasi proses penyelesaian masalah.

Rencana Pelaksanaan Pembelajaran (RPP) dikembangkan dari silabus untuk mengarahkan kegiatan pembelajaran peserta didik dalam upaya mencapai kompetensi dasar (KD). Rancangan RPP yang akan dikembangakan sebanyak enam kali pertemuan. Pada tahap merancang RPP, peneliti berpedoman pada Permendikbud Nomor 22 Tahun 2016 tentang Standar Proses Pendidikan Dasar dan Menengah peneliti merancang dan menyusun semua komponen RPP yang akan dikembangkan. Langkah-langkah pembelajaran terdiri dari kegiatan pendahuluan, kegiatan inti dan penutup. Kegiatan inti disesuaikan dengan langkah-langkah model Problem Based Learning, tahapannya yaitu: (1) orientasi siswa pada masalah; (2) pengorganisasian siswa; (3) pembimbingan dalam penyelidikan 
kelompok; (4) pengembangan dan penyajian hasil karya; dan (5) mengevaluasi hasil karya. Berdasarkan langkah-langkah model Problem Based Learning dimulai dengan kegiatan pemberian stimulus dan masalah kontekstual dalam kehidupan sehari-hari. RPP

Lembar Aktifitas Siswa (LAS). LAS yang dikembangkan berisi lembar aktivitas yang diisi oleh siswa berdasarkan tahapan model PBL untuk memecahkan masalah sehingga dapat menemukan konsep dari materi pembelajaran. Langkah-langkah kegiatan disusun sesuai dengan model PBL dan pendekatan saintifik. Rancangan LAS dibuat berwarna sehingga siswa tertarik dan termotivasi untuk belajar. Keseluruhan perangkat pembelajaran disesuaikan dengan model PBL agar menjadi satu kesatuan untuk kemudian diharapkan penerapannya berdampak pada peningkatan kemampuan pemecahan masalah matematis siswa. Rancangan format LAS terdiri dari rancangan cover LAS, dan isi.

\section{Tahap Pengembangan (Development)}

Pada tahap ini kegiatan pengembangan adalah memproduksi atau membuat atau spesifikasi produk pembelajaran yang telah ditentukan pada tahap desain adalah silabus, RPP, dan LAS. Berikut contoh silabus, RPP, dan LAS yang telah dikembangkan.

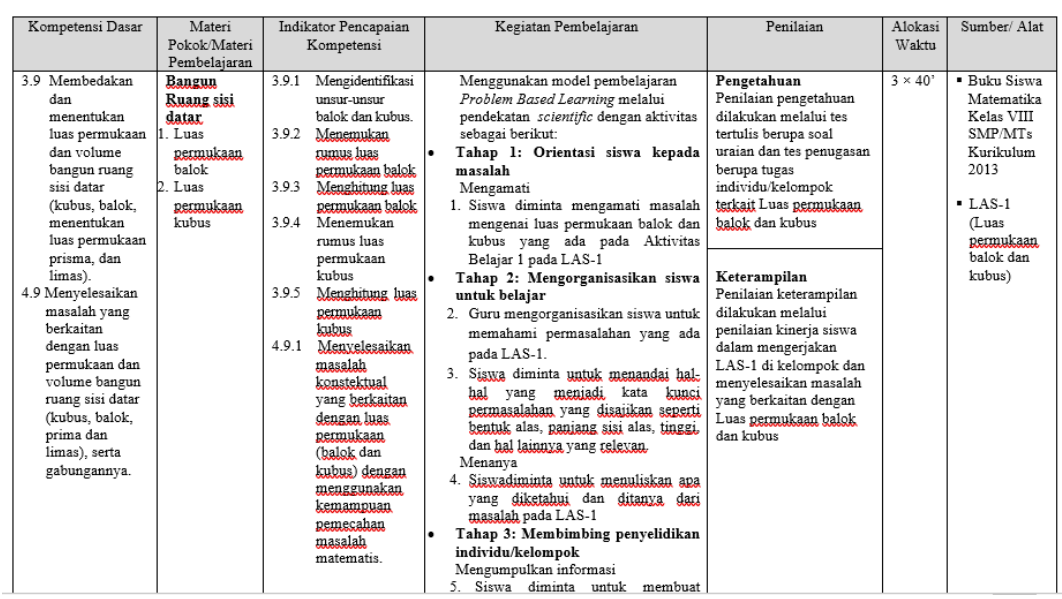

Gambar 2. Hasil Pengembangan Silabus

B. Kompetensi Dasar (KD) dan Indikator Pencapaian Kompetensi (IPK)

\begin{tabular}{|c|cl|}
\hline Kompetensi Dasar (KD) & Indikator Pencapaian Kompetensi (IPK) \\
\hline $3.9 \begin{array}{l}\text { Membedakan dan menentukan } \\
\text { luaspermukaan dan volumebangun } \\
\text { ruang sisi datar (kubus, balok, } \\
\text { prisma, dan limas) }\end{array}$ & 3.9 .1 & $\begin{array}{l}\text { Mengidentifikasi unsur-unsur balok } \\
\text { dan kubus }\end{array}$ \\
& $3.9 .2 \begin{array}{l}\text { Menemukan rumus luas permukaan } \\
\text { balok }\end{array}$ \\
& $3.9 .4 \begin{array}{l}\text { Menghitung luas permukaan balok } \\
\text { Menemukan rumus luas permukaan } \\
\text { kubus }\end{array}$ \\
\hline $\begin{array}{l}\text { Menyelesaikan masalah yang } \\
\text { berkaitan dengan luas permukaan } \\
\text { dan volume bangun ruang sisi datar } \\
\text { (kubus, balok, prisma, dan limas). }\end{array}$ & 3.9 .1 & $\begin{array}{l}\text { Menyelesaikan masalah konstektual } \\
\text { yang berkaitan dengan luas } \\
\text { permukaan (balok dan kubus) dengan } \\
\text { menggunakan kemampuan } \\
\text { pemecahan masalah. }\end{array}$ \\
\hline
\end{tabular}

Gambar 3. Hasil Pengembangan RPP

LAS disusun menggunakan tahapan model PBL dan pendekatan saintifik yang memuat indikator pemecahan masalah matematis. LAS dilengkapi dengan judul, kotak penulisan nama peserta 
Pengembangan Perangkat Pembelajaran Matematika Berbasis Model Problem Based Learning untuk Memfasilitasi Kemampuan Pemecahan Masalah Siswa Kelas VIII SMP/MTs, Reny Reski, Nahor Murani Hutapea, Sehatta Saragih 709

didik beserta nama anggota kelompok, petunjuk penggunaan dan tujuan pembelajaran. LAS diawali dengan menampilkan permasalahan berupa soal cerita dalam kehidupan sehari-hari. LAS yang didesain dengan gambar-gambar yang menarik agardapat memotivasi peserta didik, serta LAS dibuat berwarna agar tampilannya menjadi lebih menarik.

LAS yang dirancang menggunakan model PBL yang memuat indikator KPMM yaitu: (1) Tahap orientasi peserta didik pada masalah, terdapat kolom "Mengamati masalah" yang berisi permasalahan berupa soal cerita yang dikehidupan nyata sesuai dengan materi yang diajarkan (2) Tahap mengorganisasikan peserta didik, terdapat kolom "Menanya" sebagai ruang bagi siswa untuk menentukan diketahui dan ditanyakan dari permasalahan yang merupakan indikator KPMM; (3) Tahap membimbing penyelidikan kelompok terdapat kolom "Menalar" sebagai ruang bagi peserta didik untuk menemukan model matematika berdasarkan permasalahan yang dibuat yang merupakan indikator dari KPMM, serta kolom "Mengumpulkan informasi" sebagai ruang bagi peserta didik untuk menentukan strategi/rencana dalam menyelesaikan masalah yang diberikan yang merupakan indikator dari KPMM; serta kolom "Menalar/mengasosiasikan" sebagai ruang bagi peserta didik dalammelaksanakan strategi yang telah diperoleh untuk menyelesaikan masalah serta menyesuaikan jawaban yang telah diperoleh dengan permintaan soal yang merupakan indikator dari KPMM; (4) Tahap mengembangkan dan menyajikan hasil karya terdapat kolom "Mengkomunikasikan" sebagai ruang bagi siswa untuk menarik simpulan berdasarkan hasil karya yang mereka lakukan, selanjutnya siswa menampilkan hasil yang diperoleh berkelompok; (5) Tahap menganalisis dan mengevaluasi proses pemecahan masalah terdapat kolom "Mengkomunikasikan" sebagai ruang bagi peserta didik untuk menyamakan hasil diskusi kelompok; (6) soal latihan untuk memfasilitasi KPMM siswa dengan terdapat kolom "Ayo berlatih". Berikut ini contoh bagian sampul dan bagian isi LAS yang telah dikembangkan.
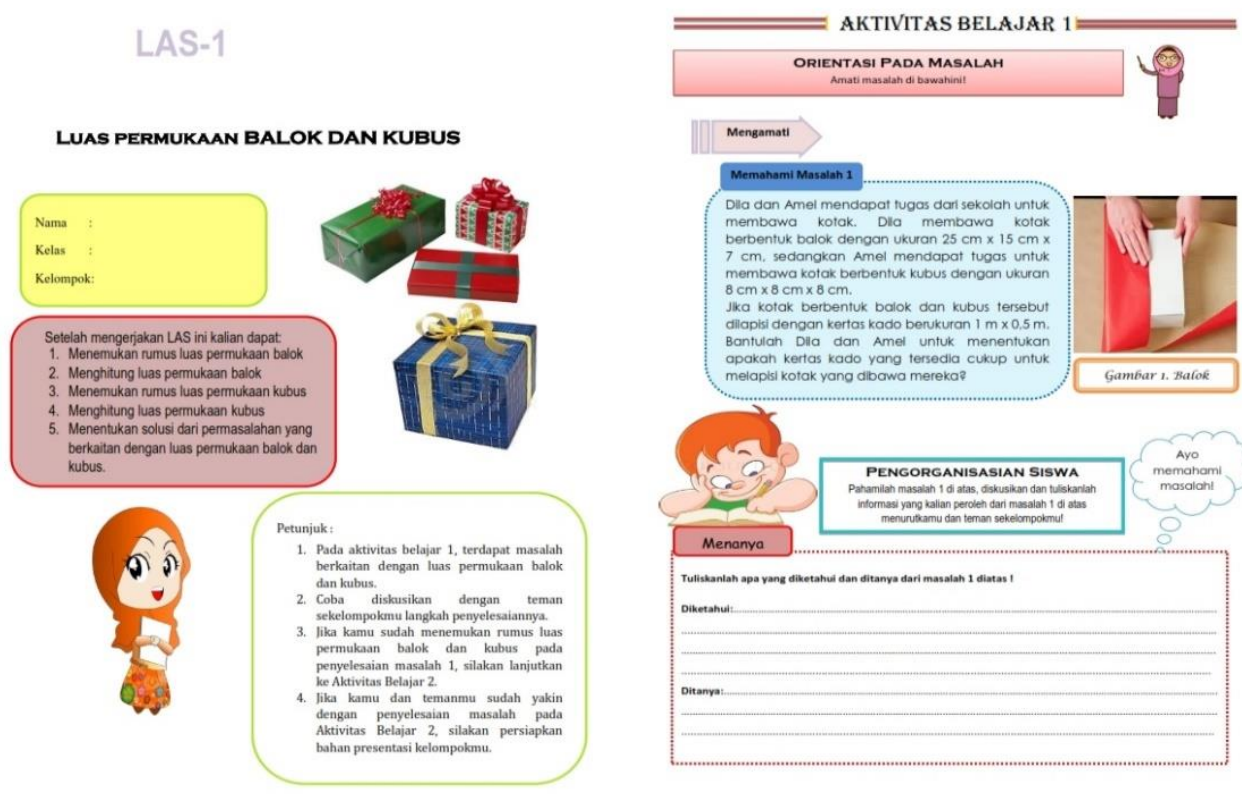

Gambar 4. Hasil Pengembangan LAS 
Perangkat pembelajaran yang telah dikembangkan selanjutnya divalidasi oleh validator. Penilaian validator terhadap silabus meliputi aspek identitas silabus, KI dan KD, indikator pencapaian kompetensi, materi pembelajaran, kegiatan pembelajaran, penilaian hasil belajar, dan sumber belajar. Hasil validasi silabus matematika berbasis Kurikulum 2013 pada materi bangun ruang sisi datar dengan model PBL untuk kelas VIII MTs terlihat pada Tabel 3 Hasil Validasi Silabus:

Tabel 3. Hasil Validasi Silabus

\begin{tabular}{|c|l|c|c|}
\hline $\begin{array}{c}\text { Aspek } \\
\text { Penilaian }\end{array}$ & \multicolumn{1}{|c|}{ Indikator Penilaian } & $\begin{array}{c}\text { Rata-rata per- } \\
\text { Indikator }\end{array}$ & $\begin{array}{c}\text { Rata-rata } \\
\text { per- Aspek }\end{array}$ \\
\hline \multirow{4}{*}{ Isi } & Kelengkapan identitas silabus & $97,22 \%$ & \\
\cline { 2 - 3 } & KI dan KD & $83,33 \%$ & \\
\cline { 2 - 3 } & Indikator pencapaian kompetensi & $86,11 \%$ & \multirow{2}{*}{$87,96 \%$} \\
\cline { 2 - 3 } & Materi pembelajaran & $91,67 \%$ & \\
\cline { 2 - 3 } & Penilaian hasil belajar & $83,33 \%$ & \\
\cline { 2 - 3 } & Sumber belajar & $86,11 \%$ & $91,67 \%$ \\
\hline Kontruksi & Kegiatan Pembelajaran & $91,67 \%$ & $89,82 \%$ \\
\hline \multicolumn{2}{|r|}{ Rata-rata Keseluruhan } \\
\hline
\end{tabular}

Dari Tabel 3 diperoleh bahwa rata-rata keseluruhan terhadap penilaian silabus sebesar 89,82\%. Berdasarkan kriteria penilaian validitas pada Tabel 3.11 penilaian silabus merupakan kriteria "sangat valid". Ketiga validator menyimpulkan bahwa silabus dapat digunakan dengan revisi kecil. Penilaian dari validator berupa koreksi, kritik, dan saran yang digunakan sebagai bahan pertimbangan dalam melakukan revisi silabus.

Penilaian validator terhadap RPP meliputi beberapa indikator yaitu kesesuaian RPP, indentitas, rumusan indikator pencapaian kompetensi, rumusan tujuan pembelajaran, materi pembelajaran, pemilihan media, alat, dan sumber belajar, teknik penilaian, perumusan kegiatan pembelajaran. Hasil validasi dan saran revisi RPP dari validator dapat dilihat pada Lampiran. Hasil validasi RPP matematika berbasis Kurikulum 2013 pada materi bangun ruang sisi datar dengan model PBL untuk kelas VIII MTs terlihat pada Tabel 4. Hasil validasi RPP

Tabel 4. Hasil validasi RPP

\begin{tabular}{|c|c|c|c|c|c|c|c|c|}
\hline \multirow{2}{*}{ Aspek Penilaian } & \multirow{2}{*}{ Indikator Penilaian } & \multicolumn{6}{|c|}{ \% rata-rata RPP per-indikator } & \multirow[b]{2}{*}{ Rata-rata } \\
\hline & & \begin{tabular}{|l|} 
RPP 1 \\
\end{tabular} & RPP 2 & RPP 3 & RPP 4 & RPP 5 & RPP 6 & \\
\hline \multirow[t]{5}{*}{ Isi } & $\begin{array}{l}\text { Kelengkapan } \\
\text { Komponen RPP }\end{array}$ & 83,3 & 83,33 & 83,33 & 83,33 & 83,33 & 83,33 & $83,33 \%$ \\
\hline & $\begin{array}{l}\text { Kesesuaian rumusan } \\
\text { indikator pencapaian } \\
\text { kompetensi }\end{array}$ & 83,33 & 83,33 & 83,33 & 83,33 & 83,33 & 87,50 & $84,02 \%$ \\
\hline & $\begin{array}{l}\text { Kejelasan tujuan } \\
\text { pembelajaran }\end{array}$ & 83,3 & 83,33 & 83,33 & 83,33 & 83,33 & 83,33 & $83,33 \%$ \\
\hline & Materi pembelajaran & 75,00 & 79,17 & 75,00 & 79,17 & 79,17 & 75,00 & $77,08 \%$ \\
\hline & $\begin{array}{l}\text { Pemilihan pendekatan, } \\
\text { model, metode } \\
\text { pembelajaran }\end{array}$ & 70,83 & 83,33 & 75,00 & 79,17 & 75,00 & 75,00 & $76,39 \%$ \\
\hline
\end{tabular}


Pengembangan Perangkat Pembelajaran Matematika Berbasis Model Problem Based Learning untuk Memfasilitasi Kemampuan Pemecahan Masalah Siswa Kelas VIII SMP/MTs, Reny Reski, Nahor Murani Hutapea, Sehatta Saragih 711

\begin{tabular}{|c|l|c|c|c|c|c|c|c|}
\hline \multirow{2}{*}{ Aspek Penilaian } & \multirow{2}{*}{ Indikator Penilaian } & \multicolumn{5}{|c|}{ \% rata-rata RPP per-indikator } & \multirow{2}{*}{ Rata-rata } \\
\cline { 2 - 9 } & $\begin{array}{l}\text { Alat, media dan } \\
\text { sumber belajar }\end{array}$ & 72,92 & 72,92 & 70,83 & 70,83 & 79,17 & 75,00 & $73,61 \%$ \\
\cline { 2 - 9 } & Penilaian hasil belajar & 75,00 & 75,00 & 75,00 & 75,00 & 75,00 & 77,78 & $75,46 \%$ \\
\hline Kontruksi & $\begin{array}{l}\text { Perumusan kegiatan } \\
\text { pembelajaran }\end{array}$ & 74,17 & 75,83 & 75,83 & 73,33 & 73,33 & 73,33 & $74,30 \%$ \\
\hline & & & & & & & & \\
\hline
\end{tabular}

Pada Tabel 4 diperoleh skor rata-rata keseluruhan terhadap penilaian RPP sebesar 75,92\%. Berdasarkan kriteria validitas, penilaian RPP tergolong kriteria "valid". Ketiga validator menyimpulkan bahwa RPP dapat digunakan dengan revisi kecil. Penilaian dari validator berupa koreksi, kritik, dan saran yang digunakan sebagai bahan pertimbangan dalam melakukan revisi rencana pelaksanaan pembelajaran (RPP).

Penilaian yang dilakukan validator terhadap LAS meliputi: Tampilan sampul LAS, Isi LAS, LAS dan syarat didikatis, LAS dan syarat konstruksi, LAS dan syarat teknis. Dalam melakukan revisi, peneliti mengacu pada hasil diskusi dengan mengikuti saran-saran serta petunjuk validator. Hasil validasi dan saran revisi LKPD dari validator dapat dilihat pada Lampiran. Hasil validasi ahli terhadap LKPD disajikan dalam Tabel 5. Hasil validasi LAS.

Tabel 5. Hasil validasi LAS

\begin{tabular}{|c|c|c|c|c|c|c|c|}
\hline \multirow{2}{*}{ Aspek penilaian } & \multicolumn{6}{|c|}{ Rata-rata per-Indikator } & \multirow{2}{*}{ Rata-rata } \\
\hline & LAS 1 & LAS 2 & LAS 3 & LAS 4 & LAS 5 & LAS 6 & \\
\hline Tampilan LAS & $100 \%$ & $100 \%$ & $100 \%$ & $100 \%$ & $100 \%$ & $100 \%$ & $100 \%$ \\
\hline Isi LAS & $91,67 \%$ & $91,67 \%$ & $91,67 \%$ & $91,67 \%$ & $91,67 \%$ & $91,67 \%$ & $91,67 \%$ \\
\hline $\begin{array}{lll}\begin{array}{l}\text { Kesesuaian } \\
\text { didaktis }\end{array} & \text { dengan } & \text { syarat } \\
\end{array}$ & $87,5 \%$ & $87,5 \%$ & $87,5 \%$ & $87,5 \%$ & $87,5 \%$ & $87,5 \%$ & $87,5 \%$ \\
\hline $\begin{array}{l}\begin{array}{l}\text { Kesesuaian dengan } \\
\text { konstruksi }\end{array} \\
\end{array}$ & $86,90 \%$ & $86,90 \%$ & $86,90 \%$ & $86,90 \%$ & $86,90 \%$ & $86,90 \%$ & $86,90 \%$ \\
\hline Kesesuaian dengan syarat teknis & $93,18 \%$ & $93,18 \%$ & $93,18 \%$ & $93,18 \%$ & $93,18 \%$ & $93,18 \%$ & $93,18 \%$ \\
\hline \multicolumn{7}{|c|}{ Rata-rata } & $91,85 \%$ \\
\hline
\end{tabular}

Dari Tabel 5 diperoleh rata-rata skor keseluruhan terhadap penilaian LAS sebesar 91,85\%. Penilaian LAS secara keseluruhan memenuhi kriteria "sangat valid". Ketiga validator menyimpulkan bahwa LAS dapat digunakan dengan revisi kecil. Dari penilaian para validator diperoleh koreksi, kritik, dan saran yang digunakan sebagai bahan pertimbangan dalam melakukan revisi LAS.

\section{Tahap Implementasi (Implementation)}

Pada tahap ini, perangkat pembelajaran yang telah divalidasi oleh para ahli dan telah memenuhi kategori valid, maka selanjutnya dilakukan uji coba. Perangkat pembelajaran tersebut diujicobakan pada kelompok kecil/ uji coba terbatas sebanyak 5-20 orang siswa. siswa diminta untuk mengisi angket respon yang bertujuan untuk menilai LAS yang sedang dikembangkan. Peneliti melakukan analisis terhadap angket respon peserta didik pada uji coba kelompok kecil dan melakukan revisi LAS sesuai dengan angket respon peserta didik tersebut. LAS yang telah direvisi kemudian diuji coba kelompok besar. 
Pada tahap uji coba kelompok kecil LAS berbasis Kurikulum 2013 pada materi pokok bangun ruang sisi datar dengan model PBL yang telah direvisi diujicobakan kepada 12 orang siswa kelas VIII MTsN 8 kampar dengan kemampuan akademis yang heterogen. Peserta didik yang terpilih berasal dari kelompok prestasi tinggi, sedang dan rendah. Uji coba kelompok kecil dilaksanakan selama 6 hari. Dikarenakan penelitian ini dilakukan pada masa pandemi covid maka pada pertemuan pertama peneliti membagikan secara langsung ke-6 LAS yang kemudian dibawa siswa pulang ke rumah, kemudian peneliti berkomunikasi memberikan arahan dan menjawab pertanyaan siswa melalui aplikasi WhatsApp (WA). Dan siswa memberikan jawaban dengan foto yang diberikan kepada peneliti kemudian mengumpulkan secara keseluruhan LAS pada hari ke-6. Siswa memberi pendapat masing-masing terhadap LAS yang baru saja mereka gunakan. Angket respon peserta didik menilai tentang LAS berdasarkan aspek keterbacaan dan struktur isi. Hasil lengkap angket respon peserta didik dari uji coba kelompok kecil dapat dilihat pada Lampiran. Berikut rata-rata persentase hasil angket respon peserta didik terhadap masing-masing LAS yang telah diujicobakan pada Tabel 6. Hasil Angket Respon Peserta Didik Uji Coba Kelompok Kecil.

Tabel 6. Hasil Angket Respon Peserta Didik Uji Coba Kelompok Kecil

\begin{tabular}{|l|c|c|c|c|c|c|c|}
\hline Aspek & LAS 1 & LAS 2 & LAS 3 & LAS 4 & LAS 5 & LAS 6 & Rata-rata \\
\hline Tampilan LAS & $98 \%$ & $95 \%$ & $96 \%$ & $94 \%$ & $94 \%$ & $95 \%$ & $95 \%$ \\
\hline Isi/Materi LAS & $90 \%$ & $93 \%$ & $87 \%$ & $84 \%$ & $86 \%$ & $89 \%$ & $88 \%$ \\
\hline Penggunaan LAS & $92 \%$ & $95 \%$ & $95 \%$ & $95 \%$ & $95 \%$ & $95 \%$ & $95 \%$ \\
\hline \multicolumn{7}{|c|}{ Rata-rata Keseluruhan } \\
\hline
\end{tabular}

Pada Tabel 6 rata-rata kepraktisan LAS pada uji coba kelompok kecil adalah 93\%. Berdasarkan Tabel 3.13 kriteria penilaian kepraktisan LAS memenuhi kriteria "sangat praktis". LAS yang dikembangkan bisa digunakan untuk uji coba kelompok besar. Pada akhir kegiatan dalam proses penelitian, peneliti berdiskusi dengan siswa untuk mendapatkan masukan dari siswa mengenai LAS yang dikerjakan. Masukan dari peserta didik kemudian dijadikan bahan pertimbangan dalam merevisi LAS. Peneliti mengacu kepada hasil pengamatan saat peserta didik mengerjakan LAS, angket respon, serta hasil diskusi dengan peserta didik. Peneliti selanjutnya, melakukan revisi terhadap LAS. Revisi yang dilakukan meliputi perbaikan terhadap kesalahan ketikan, perbaikan pada kolom jawaban peserta didik yang dinilai terlalu kurang mencukupi, serta perbaikan kalimat intruksi pada LAS dengan kalimat yang dipahami oleh peserta didik.

\section{DISKUSI}

Penelitian pengembangan yang dimaksud dalam penelitian ini adalah mengembangkan perangkat pembelajaran matematika berbasis model PBL berupa Silabus, RPP dan LAS yang dapat memfasilitasi kemampuan pemecahan masalah siswa pada materi bangun ruang sisi datar kelas VIII. Perangkat pembelajaran yang telah dikembangkan, dinilai validitas, dan kepraktisannya. Uji validitas perangkat pembelajaran dilakukan oleh tiga orang validator, dimana setiap validator memberikan 
penilaian pada setiap perangkat pembelajaran. Perangkat yang sudah divalidasi, dilakukan uji coba kelompok kecil pada 12 orang siswa untuk menilai kepraktisan LAS.

Aspek yang dinilai pada silabus ini terdiri atas dua aspek yaitu aspek isi dan aspek konstruk. Kedua aspek ini diberikan penilaian pada validator dan memperoleh nilai sebagai berikut: aspek isi meliputi identitas silabus dengan nilai yang diberikan validator adalah 97,22\% berarti komponen silabus sudah sesuai dengan Permendikbud no. 22 tahun 2016. Pada pemilihan "Kompetensi Dasar (KD) dijabarkan dalam IPK dan terkait antara KD rata-rata yang diberikan validator yaitu 83,33\% dengan kategori valid. Pada teknik penilaian diperoleh nilai $83,33 \%$ yang berarti teknik penilaian sudah valid sesuai dengan teknik penilaian dengan penilaian autentik yang terbagi atas penilaian pengetahuan dan keterampilan. Untuk ketepatan alokasi waktu, kesesuaian sumber belajar dan penilaian tes kemampuan pemecahan masalah matematis, diperoleh nilai $83,33 \%$ dan $91,67 \%$ yang artinya alokasi waktu yang ditetapkan sudah cukup dengan materi pembelajaran yang akan disampaikan dalam pembelajaran, sumber belajar yang dipilih mendukung ketercapaian KD dan karakteristik peserta didik. Aspek kontruksi yang meliputi kegiatan pembelajaran yang disesuaikan dengan langkah-langkah model PBL dan pendekatan saintifik diperoleh nilai 91,67\% dengan kategori valid. Kegiatan pembelajaran tersebut sudah sesuai dengan model PBL dan pendekatan saintifik.

Silabus yang dikembangkan oleh peneliti memenuhi kriteria valid. Hal ini diperoleh berdasarkan analisis data kevalidan silabus yang mencapai skor rata-rata 89,82\%. Silabus yang dikembangkan dinilai telah sesuai dengan ketentuan yang diatur dalam Permendikbud nomor 22 tahun 2016 tentang Standar Proses Pendidikan Dasar dan Menengah. Namun menurut validator, masih diperlukan perbaikan pada pembuatan media pembelajaran yang digunakan dan kepala tabel pada setiap halaman silabus. Hal ini bertujuan untuk memudahkan dalam pengembangan RPP, sebab menurut Sa’dun Akbar (2013) silabus digunakan sebagai acuan dalam pengembangan RPP.

Penilaian validasi pada RPP sama halnya dengan silabus yang terdiri atas dua aspek yaitu aspek isi dan aspek konstruk. Aspek isi meliputi: aspek kesesuaian RPP dan indentitas pada RPP adalah 79,03\% dan 74,30\%. Berdasarkan nilai tersebut komponen RPP sudah lengkap dan sesuai dengan Permendikbud no 22 tahun 2016. Kesesuaian rumusan indikator pencapaian kompetensi (IPK) dengann $\mathrm{KD}$, nilai yang diberikan $84.02 \%$ dan kesesuaian rumusan tujuan pembelajaran dengan IPK, nilai yang diberikan validator adalah $83,33 \%$, artinya IPK sesuai dengan KD dan tujuan pembelajaran sesuai dengan IPK yang telah ditetapkan. Kesesuaian materi pembelajaran yang memuat fakta, konsep, prinsip dan prosedur diperoleh nilai 77,08\% artinya materi pembelajaran pada RPP sesuai dan memuat fakta, konsep, prinsip dan prosedur. Kesesuaian cakupan materi pembelajaran dengan alat/media pembelajaran, dengan sumber belajar, dan kesesuaian cakupan materi pembelajaran dengan pengalaman peserta didik, nilai yang diberikan validator adalah 77,08\%. Pada aspek konstruk meliputi perumusan kegiatan pembelajaran yang disesuaikan dengan langkah-langkah model PBL juga dinilai valid dengan nilai 74,30\% artinya langkah-langkah model pembelajaran dapat digunakan untuk mencapai tujuan pembelajaran dan menumbuhkan keaktifan peserta didik. RPP yang peneliti kembangkan memenuhi 
kriteria valid. Hal ini diperoleh berdasarkan analisis data kevalidan RPP yang mencapai skor rata-rata keseluruhan $75,92 \%$.

Nilai validasi yang diberikan validator pada LAS terdapat beberapa aspek, yaitu tampilan sampul LAS, isi LAS, LAS dan syarat didaktis, LAS dan syarat konstruksi, LAS dan syarat teknis. Validasi aspek tampilan sampul LAS dengan rata-rata 100\%. Validasi aspek isi LAS dengan rata-rata 91,67\%. Validasi aspek LAS dan syarat didaktis dengan rata-rata 87,50\%. Validasi aspek LAS dan syarat konstruksi dengan rata-rata $86,90 \%$. Validasi aspek LAS dan syarat teknis dengan rata-rata 93,18\%. LAS yang dikembangkan oleh peneliti memenuhi kriteria sangat valid. Hal ini diperoleh berdasarkan analisis data kevalidan LAS yang mencapai skor rata-rata keseluruhan 91,85\%. LAS yang dikembangkan dinilai telah memenuhi syarat-syarat pengembangan LAS menurut Trianto (2011) yaitu syarat didaktik, syarat konstruksi dan syarat teknis.

LAS yang sudah divalidasi, lalu diujicobakan pada uji coba kelompok kecil. Uji coba ini untuk melihat keterbacaan dan kepraktisan. Berdasarkan hasil yang diperoleh dari uji coba kelompok kecil dengan 12 orang peserta didik, diperoleh nilai rata-rata persentase dari angket respon peserta didik mencapai 96,44\% dengan kategori sangat praktis dan saran revisi dari responden untuk perbaikan sebelum dilakukan uji coba kelompok besar.

Berdasarkan hasil penilaian validator terhadap kevalidan perangkat pembelajaran yang dikembangkan diperoleh dengan kriteria sangat valid dan valid. Dengan demikian, perangkat pembelajaran yang dikembangkan telah memenuhi kualifikasi valid karena telah mencapai kriteria minimal baik (Rahayu \& Kholillah, 2018). Hal ini menunjukkan bahwa konsep, gambar, istilah, dan data atau fakta yang digunakan dalam perangkat pembelajaran ini sudah akurat secara umun. Akan tetapi, terdapat beberapa revisi dari validator terkait istilah dan penulisan yang digunakan. Perangkat pembelajaran yang telah dikembangkan dapat digunakan dalam proses pembelajaran setelah melalui tahap validasi.

Sesuai dengan pendapat (Nieveen, 1999) yang mengatakan bahwa aspek kevalidan mengacu pada apakah perangkat perangkat pembelajaran yang dikembangkan telah sesuai teoritiknya dan terdapat konsistensi internal pada setiap komponennya. Selain itu, perangkat pembelajaran dikatakan valid, jika penilaian ahli menunjukkan bahwa pengembangan perangkat tersebut dilandasi oleh teori yang kuat dan memiliki konsistensi internal, yakni terjadi saling keterkaitan antar komponen dalam perangkat yang dikembangkan (Mustami \& Irwansyah, 2015). Selain itu, suatu produk dikatakan berkualitas jika memenuhi 3 kriteria, yaitu valid, praktis dan efektif. Hal tersebut sesuai dengan pendapat Fauzan, Plomp, \& Gravemeijer, bahwa kriteria untuk mendapatkan kualitas produk yang baik yaitu valid, praktis dan efektif (Desmaniati \& Fitriza, 2019). Dalam menilai kepraktisan pada perangkat ini, maka dikumpulkan data melalui observasi dan wawancara dengan pendidik dan angket praktikalitas yang diisi oleh peserta didik. Hal ini menunjukkan bahwa perangkat pembelajaran berbasis model $P B L$ untuk meningkatkan kemampuan pemecahan masalah matematis peserta didik valid dan praktis. 


\section{KESIMPULAN}

Penelitian pengembangan ini menghasilkan suatu perangkat pembelajaran matematika berupa silabus, RPP, dan LAS pada materi Bangun ruang sisi datar yang menerapkan model PBL. Peneliti mengembangkan perangkat pembelajaran matematika dengan menggunakan model ADDIE. Berdasarkan hasil penelitian dan pembahasan pada Bab IV diperoleh simpulan sebagai berikut: 1) produk pengembangan berupa perangkat pembelajaran matematika dengan model PBL pada materi bangun ruang sisi datar telah memenuhi kriteria validitas dengan kategori valid; dan 2) produk pengembangan berupa perangkat pembelajaran matematika dengan model PBL pada materi bangun ruang sisi datar telah memenuhi kriteria kepraktisan dengan tingkat kepraktisan berada pada kategori sangat praktis. Perlu disadari bahwa penelitian ini tentunya masih memiliki beberapa kelemahan. Oleh karena itu, aada beberapa saran yang dapat peneliti beri sehubungan dengan penelitian ini dalam rangka mengembangkan perangkat pembelajaran adalah sebagai berikut: 1) produk dari penelitian ini telah memenuhi aspek valid dan syarat praktikalitas sehingga dapat dijadikan sebagai salah satu alternatif perangkat pembelajaran untuk digunakan guru dalam proses pembelajaran; 2) pengembangan LAS pada penelitian ini dapat dilanjutkan. Uji coba LAS yang dikembangkan dapat dilakukan hingga uji coba skala besar pada peserta didik yang belum mempelajari materi Bangun ruang sisi datar agar diperoleh hasil penelitian yang lebih akurat; 3) pengembangan perangkat matematika model PBL untuk meningkatkan kemampuan pemecahan masalah matematis peserta didik dapat dilakukan pada materi pembelajaran matematika lainnya atau bahkan dapat diterapkan pada mata pelajaran lain; 4) pengembangan perangkat matematika model PBL diperlukan waktu yang lebih banyak untuk menyelesaikan LAS pemecahan masalah jika dibandingkan dengan pembelajaran konvensional sehingga guru dituntut dapat mengatur waktu secara efektif dan dapat mengondisikan kelas dengan baik agar dapat mencapai sasaran yang diinginkan terutama pada saat diskusi sehingga keadaan kelas tetap kondusif dan tidak mengurangi waktu untuk membahas hasil diskusi kelompok; dan 5) sebelum pelaksanaan pembelajaran sebaiknya siswa diberikan sosialisasi terlebih dahulu terkait bagaimana pembelajaran yang akan dilaksanakan agar dalam pelaksanaannya dapat berjalan lebih lancar.

\section{UCAPAN TERIMA KASIH}

Terima kasih penulis ucapkan kepada seluruh pihak yang sudah membantu dalam terselenggaranya penelitian sampai dengan dilakukannya publikasi artikel ini.

\section{DAFTAR PUSTAKA}

Akbar, S. (2013). Instrumen Perangkat Pembelajaran. PT Remaja Rosdakarya.

Anisa, W. N. (2014). Peningkatan Kemampuan Pemecahan Masalah dan Komunikasi Matematik Melalui Pembelajaran Pendidikan Matematika Realistik Untuk Siswa SMP Negeri di Kabupaten Garut. Jurnal Pendidikan Dan Keguruan, 1(1), 209668.

Arends, R. I. (2012). Learning to Teach (9th ed.). McGraw-Hill.

Bidasari, F. (2017). Pengembangan Soal Matematika Model PISA pada Konten Quantity untuk 
Mengukur Kemampuan Pemecahan Masalah Matematika Siswa Sekolah Menengah Pertama. Jurnal Gantang, 2(1), 63-78. https://doi.org/10.31629/jg.v2i1.59

Desmaniati, E., \& Fitriza, R. (2019). Praktikalitas Perangkat Pembelajaran Transformasi Geometri Berbasis Flipped Classroom Pada Peserta Didik Kelas XI SMAN 1 Padang. Math Educa Journal, 3(1), 1-12. https://doi.org/10.15548/mej.v3i1.231

Hamidy, A., \& Jailani, J. (2019). Kemampuan proses matematis siswa Kalimantan Timur dalam menyelesaikan soal matematika model PISA. Jurnal Riset Pendidikan Matematika, 6(2), 133-149. https://doi.org/10.21831/jrpm.v6i2.26679

Kamarullah, K. (2017). PENDIDIKAN MATEMATIKA DI SEKOLAH KITA. Al Khawarizmi: Jurnal Pendidikan Dan Pembelajaran Matematika. https://doi.org/10.22373/jppm.v1i1.1729

Kartika, Y., Hutapea, N. M., \& Kartini. (2020). Mathematical Learning Development using Discovery Learning Model to Improve Mathematical Understanding Skills of Students. Journal of Educational Sciences, 4(1), 124-132. https://doi.org/10.31258/jes.4.1.p.124-132

Kusmanto, H., \& Marliyana, I. (2014). Pengaruh Pemahaman Matematika Terhadap Kemampuan Koneksi Matematika Siswa Kelas Vii Semester Genap Smp Negeri 2 Kasokandel Kabupaten Majalengka. Eduma: Mathematics Education Learning and Teaching, 3(2). https://doi.org/10.24235/eduma.v3i2.56

Mulyatiningsih, E. (2012). Metode Penelitian Terapan Bidang Pendidikan. Alfabeta.

Mustami, M. K., \& Irwansyah, M. (2015). Pengembangan Lembar Kerja Peserta Didik (LKPD) Berorientasi Pendekatan Saintifik Pada Mata Pelajaran Biologi SMA. Lentera Pendidikan: Jurnal Ilmu Tarbiyah Dan Keguruan, 18(2), 236-247. https://doi.org/https://doi.org/https://doi.org/10.24252/lp.2015v18n2a8

Nieveen, N. (1999). Prototyping to Reach Product Quality. In Design Approaches and Tools in Education and Training. Springer.

Ningsih, F., Murni, A., \& Roza, Y. (2020). Development of Learning Tools with the Application of Learning Inventions to Improve Mathematical Problem Solving Ability Social Arithmetic Material. Journal of Educational Sciences, 4(1), 44-52. https://doi.org/10.31258/jes.4.1.p.44-52

Nurfatanah, Rusmono, \& Nurjannah. (2019). Kemampuan Pemecahan Masalah Matematis Siswa Sekolah Dasar. Prosiding Seminar Dan Diskusi Nasional Pendidikan Dasar 2018, 546-551. https://doi.org/10.31227/osf.io/a5qyh

Pai'pinan, M., \& Kho, R. (2018). Analisis Keterampilan Geometris Siswa SMP Berdasarkan Gaya Kognitif Dalam Menyelesaikan Masalah Geometri Tiga Dimensi. Jurnal Ilmu Sosial Dan Pendidikan, 2(3), 186-190.

Putri, A., Roza, Y., \& Maimunah. (2020). Development of Learning Tools with the Discovery Learning Model to Improve the Critical Thinking Ability of Mathematics. Journal of Educational Sciences, $7(1), 33-44$.

Rahayu, P., \& Kholillah. (2018). Validitas dan Praktikalitas Lembar Kerja Siswa Berbasis Pendekatan Kontekstual Materi Bangun Ruang Sisi Datar Pada Siswa Smp. Jurnal Ilmiah Pendidikan Matematika, 3(2), 126 - 133. https://doi.org/10.26877/jipmat.v3i2.2805

Rianti, R., Saragih, S., \& Zulkarnain. (2020). Pengembangan Perangkat Pembelajaran Matematika Dalam Konteks Budaya Melayu Riau Untuk Meningkatkan Kemampuan Pemecahan Masalah Matematis Peserta Didik. Journal Of Educational Sciences, 4(1), 73-82.

Sumartini, T. S. (2016). Peningkatan Kemampuan Pemecahan Masalah Matematis Siswa melalui 
Pengembangan Perangkat Pembelajaran Matematika Berbasis Model Problem Based Learning untuk Memfasilitasi Kemampuan Pemecahan Masalah Siswa Kelas VIII SMP/MTs, Reny Reski, Nahor Murani Hutapea, Sehatta Saragih 717

Pembelajaran Berbasis Masalah. Mosharafa: Jurnal Pendidikan Matematika, 8(3), 148-158.

Supriadi, Wildan, \& Laksmiwati, D. (2019). Implementasi Model Pembelajaran Berbasis Masalah dan Pengaruhnya terhadap Perkembangan Karakter Mahasiswa. Jurnal Penelitian Pendidikan IPA, 6(1), 63-68. https://doi.org/10.29303/jppipa.v6i1.323

Susilana, R., \& Ihsan, H. (2014). Pendekatan Saintifik Dalam Implementasi Kurikulum 2013 Berdasarkan Kajian Teori Psikologi Belajar. Edutech, 13(2), 183. https://doi.org/10.17509/edutech.v13i2.3095

Susilowati, J. P. A. (2016). Profil Penalaran Siswa SMP dalam Pemecahan Masalah Matematika Ditinjau dari Perbedaan Gender. Jurnal Review Pembelajaran Matematika. https://doi.org/10.15642/jrpm.2016.1.2.132-148

Trianto. (2011). Model Pembelajaran Terpadu (konsep, strategi, dan implementasinya dalam kurikulum tingkat satuan pendidikan KTSP). Bumi Aksara. 